\title{
Biomineralogical Phenomena in Hip Joint Endoprostheses
}

\section{Pawlikowski M* \\ AGH - University of Science and Technology, Cath. Mineralogy, Petrography and Geochemistry, Poland}

*Corresponding author: Maciej Pawlikowski, AGH - University of Science and Technology, Cath. Mineralogy, Petrography and Geochemistry, Cracow, Poland, Email: mpawlik@agh.edu.pl

\section{Research Article \\ Volume 2 Issue 2}

Received Date: October 23, 2018

Published Date: November 08, 2018

DOI: $10.23880 /$ ijtps-16000124

\section{Abstract}

Tests were performed on elements of hip joint endoprostheses regarding aging of the materials, structures of the metals as well as the cements used to fix the implant to the bone."Worn out" elements of endoprostheses after different periods of functioning were also studied.

It was determined that aging of the polymers leads to their cracking, which shortens the time of proper functioning of the acetabula and the whole artificial joints. In the "working" metal elements (femoral heads) creation of micro slag bits in the steel was observed. Those bits break out from the steel during the functioning of the hip joint, damaging the surface finishing of the head of the implant and the inner surface of the acetabulum.

Long-term load on the acetabula leads to changes in the atomic structure of the polypropylene that they are built of. That causes the acetabula to wear out faster.

Two-component fixing cements that were tested contained air bubbles as a result of mixing the components. Their presence weakens the endoprosthesis stabilization, accelerating the necessity to replace it.

Keywords: Hip joint; Endoprostheses; Acetabula; Metal elements

\section{Introduction}

Using joint endoprostheses is more and more common and effective in orthopedics. Therefore it is important to recognize the quality of materials used in such orthopedic procedures. The quality of materials, along the surgical techniques, is one of the main factors affecting the correct process of the surgery and the time of proper functioning of the endoprostheses.
Among the causes of joint dysfunctions, including hip joint, are changes in the joint cartilage. One of the causes of such changes is cartilage biomineralization occurring as a result of crystallization in structurally defective collagen (Pawlikowski 2017, in print). Said biomineralization leads to changes in the properties of cartilage collagen, the effect of which is formation of areas of increased hardness in cartilage that eventually result in complete destruction of cartilage and often 


\section{International Journal of Transplantation \& Plastic Surgery}

immobilization of the joint (Figures 1-3).

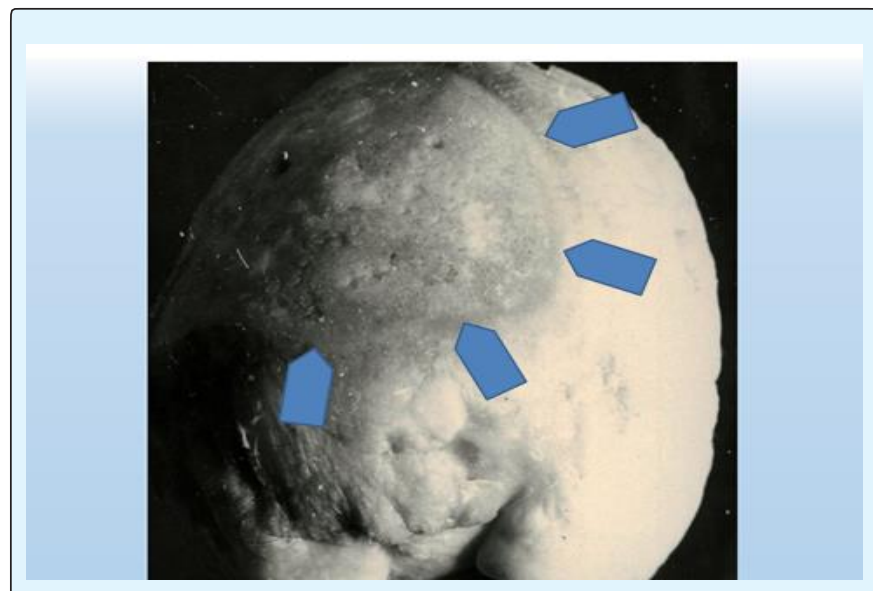

Figure 1: Femoral head with an area of completely destroyed cartilage (arrows).

Elements of endoprostheses for studies were chosen from elements kept long before implantation as well as post-surgical hip joint endoprostheses. The author would like to thank prof. dr n. med. Tadeusz Niedźwiedzki from the Rydygier hospital in Cracow for donating research materials.

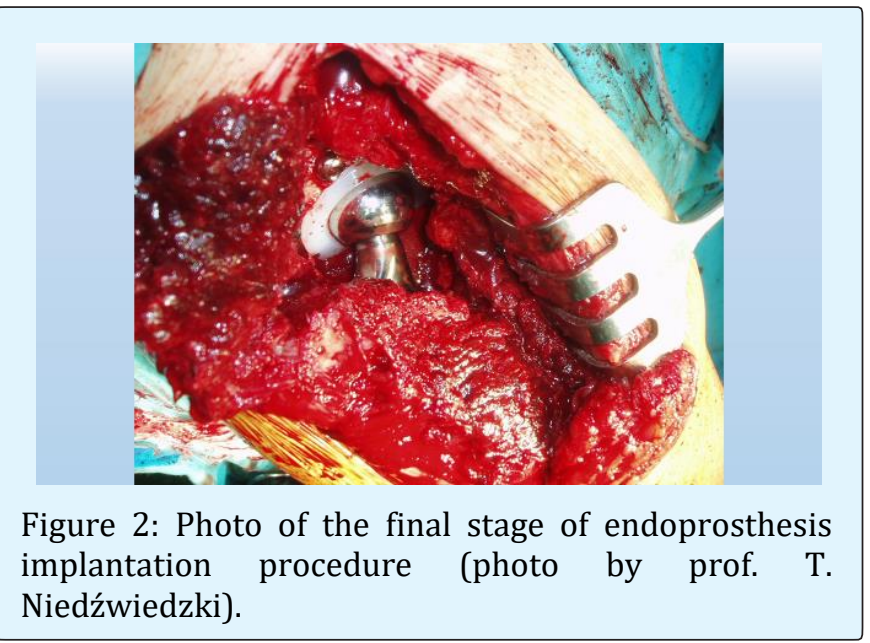

Due to space restrictions, only selected results of the endoprosthesis studies were presented in this publication. Further information can be found in cited literature [125]. Research financed from the author's private funds.

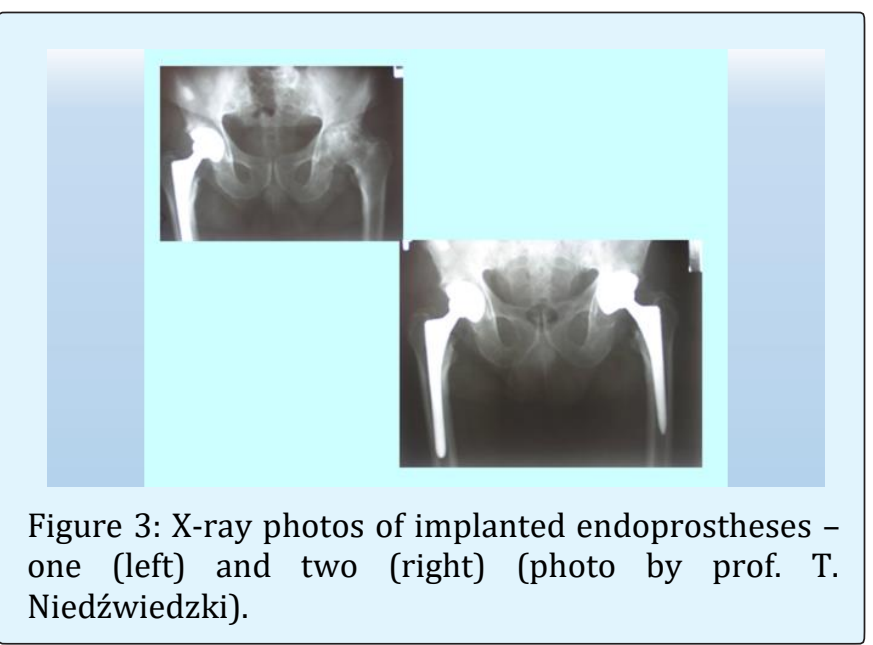

Elements of endoprostheses for studies were chosen from elements kept long before implantation as well as post-surgical hip joint endoprostheses. The author would like to thank prof. dr n. med. Tadeusz Niedźwiedzki from the Rydygier hospital in Cracow for donating research materials.

\section{Acetabula}

In the studies of acetabula, particular attention was paid to those that had been unused for a long time, to see if any changes occurred in them due to their "aging". Some new acetabula have a distinctive surface in sockets, which is the result of polymer processing and formation of the socket (Figures 4 \& 5A).

Another problem that was studied was potential changes in the structure of acetabula related to their prolonged usage.

\section{Aging of Acetabula}

Studies of acetabula that have been waiting to be implanted for a long time indicate that they can be affected by the process of polymer aging, which may lead to formation of numerous cracks (Figures $5 \& 6$ ). Those cracks are absolutely invisible to the naked eye. Their consequence - when implanted - may be the possibility of breaking off of polymer fragments that may then get into the working zone between the endoprosthesis head and socket. 


\section{International Journal of Transplantation \& Plastic Surgery}

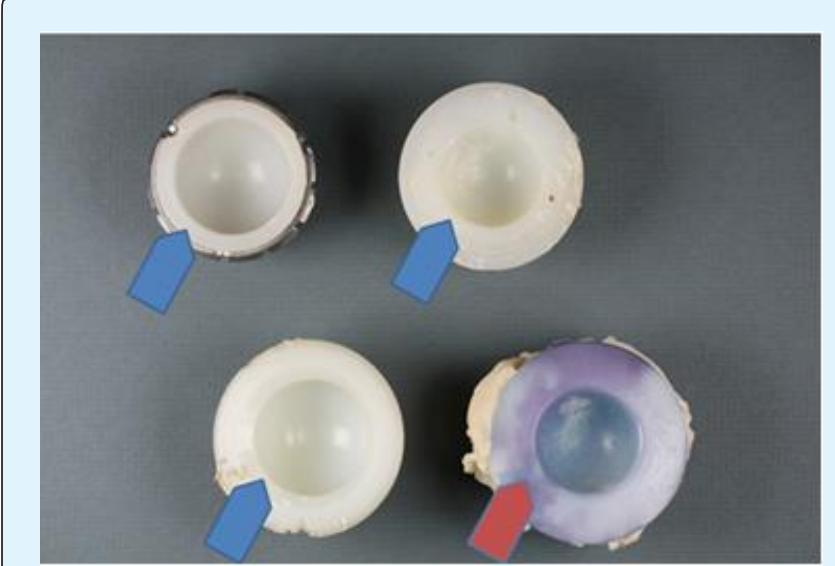

Figure 4: Studied acetabula. New acetabula that were unused for a long time (blue arrows). One of the acetabula taken out of the joint after a few years of functioning (with some fixing cement, red arrow).

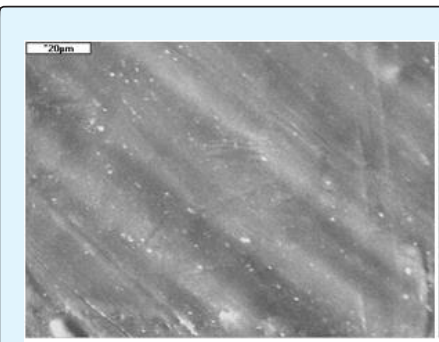

A

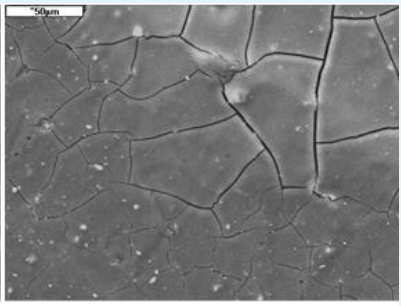

B
Figure 5, A: Surface of the acetabulum socket processed by machining; SEM. B: Surface of old, unused acetabulum affected by the process of polymer aging, leading to formation of microcrystalline domains and cracks of 3-4 $\mu \mathrm{m}$ width; SEM.

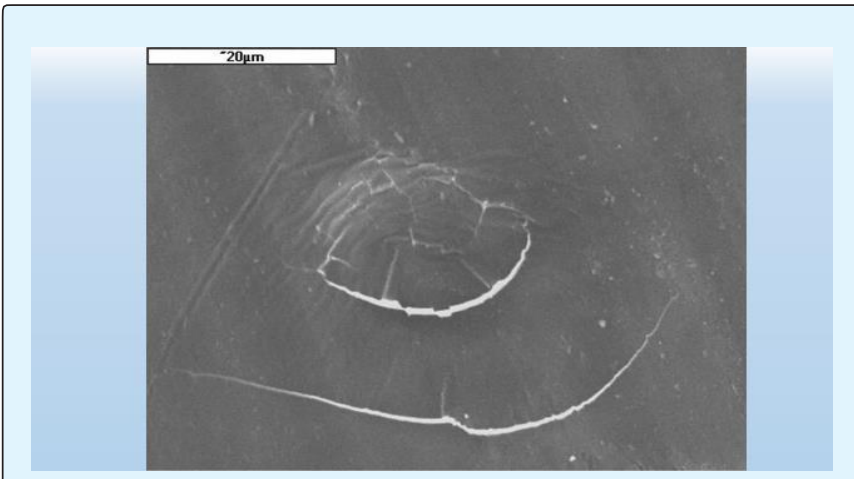

Figure 6: Image of the inside of acetabulum socket affected by structural changes due to the aging of polymer. Visible cracks of 1-2 $\mu \mathrm{m}$ width SEM.
The above studies indicate that acetabula should be checked for defects before being implanted - preferably by microscopic observation.

\section{Processes of "Wearing out" Elements of Endoprosthesis During Functioning}

Processes of endoprostheses deterioration affect both sockets (plastic elements) and "working" metal elements.

Within acetabula, especially their elements that take the load during walking, structural changes are observed microscopically as the change of interference colors of polarized light.

The process of machining the socket in acetabula causes changes in very thin surface layer and they are insignificant. Under the microscope we can see that the part designed to take the load (the socket of the acetabulum) is microscopically the same as its other parts (Figure 7).

Acetabula taken out of the joint after a longer (several years) usage show in the same place changes of interference colors (Figure 8), which are connected with changes of the atomic structure of the polymer. At this point in research, it is difficult to say what the changes are. Preliminary observations indicate that the process is irregular and leads to increasing the hardness of polymers that build the socket. The phenomenon may promote cracking of the surface layers of the sockets and shifting the resulting fragments into the joint space.

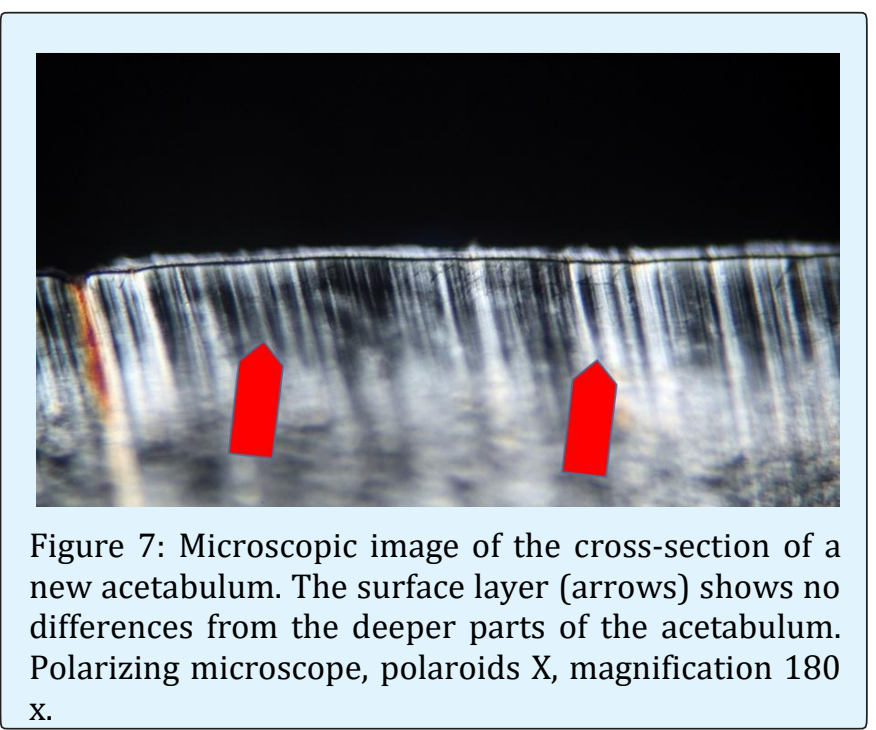




\section{International Journal of Transplantation \& Plastic Surgery}



\section{Mechanical Damage in "Working" Surface of the Acetabula}

Marks of damage on this surface differ; usually they are the result of rubbing away of the socket polymer, which is softer than the steel head of the endoprosthesis.

In case when some foreign objects (bits of steel or micro bits of slags from the steel element) get into the joint space of the endoprosthesis, the damage of the socket surface have a distinct appearance and clearly "oscillating" character.

Resulting scratches show that the tiny destructive element moved over the socket surface back and forth. The effect of this phenomenon is not only damage to the surface of the socket, but also introducing small bits of plastic into the joint surface of the endoprosthesis (Figure 9).

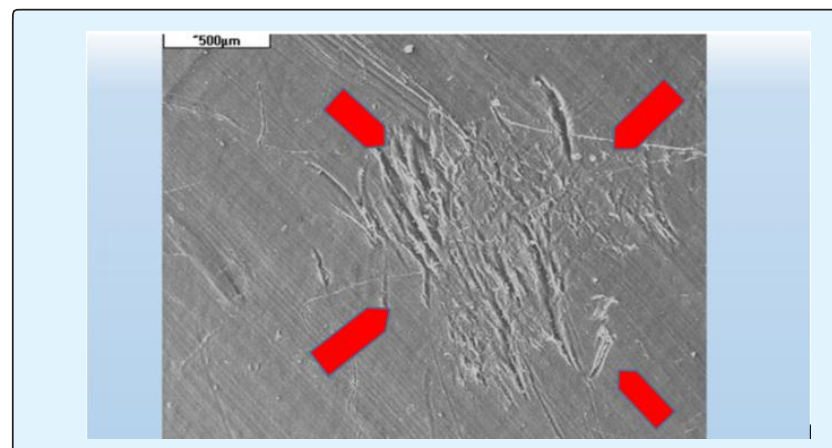

Figure 9: "Oscillating" marks of socket surface damage as a result of movement of the damaging fragment. SEM.
Another effect of deterioration of the socket surface is visible under the scanning microscope as rubbing off of its surface. That process, related to the load on the joint and resulting changes in the structure of the polymer, causes distinct marks to appear (Figure 10). Their formation leads also to breaking off of small bits of polymer from the socket and their introduction into the joint space of the endoprosthesis. Further relocation of those propylene micro grains cannot be ruled out.

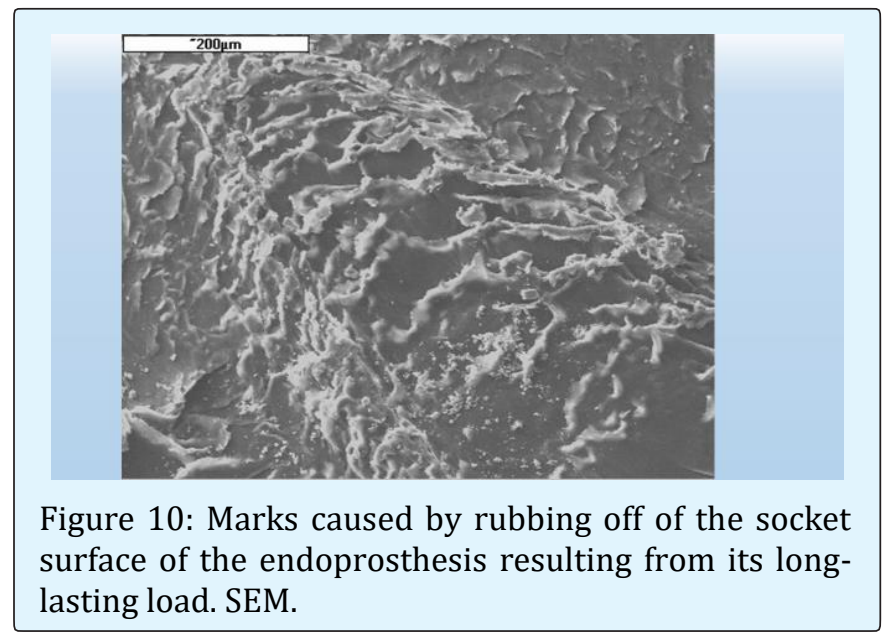

A special case is crystallization of various substances such as oxalates, carbonates or phosphates in the joint space of the endoprosthesis. Their formation is usually connected with various dysfunctions outside of joints (kidney function disorders etc.).

Minerals crystallizing in the joint space and its area often have significant hardness, and in spite of their crystals being as small as 20-30 $\mu \mathrm{m}$ (Figures 11 \& 12), they may wreak havoc in a functioning endoprosthesis. They act like grains of sand hindering or even preventing the functioning of the endoprosthesis. The result may also be swelling of the joint and other problems.

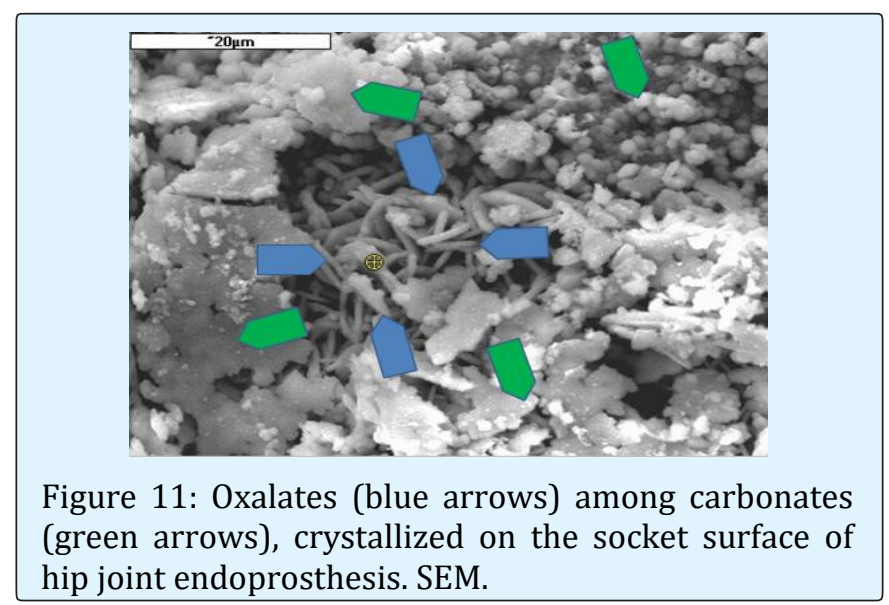




\section{International Journal of Transplantation \& Plastic Surgery}

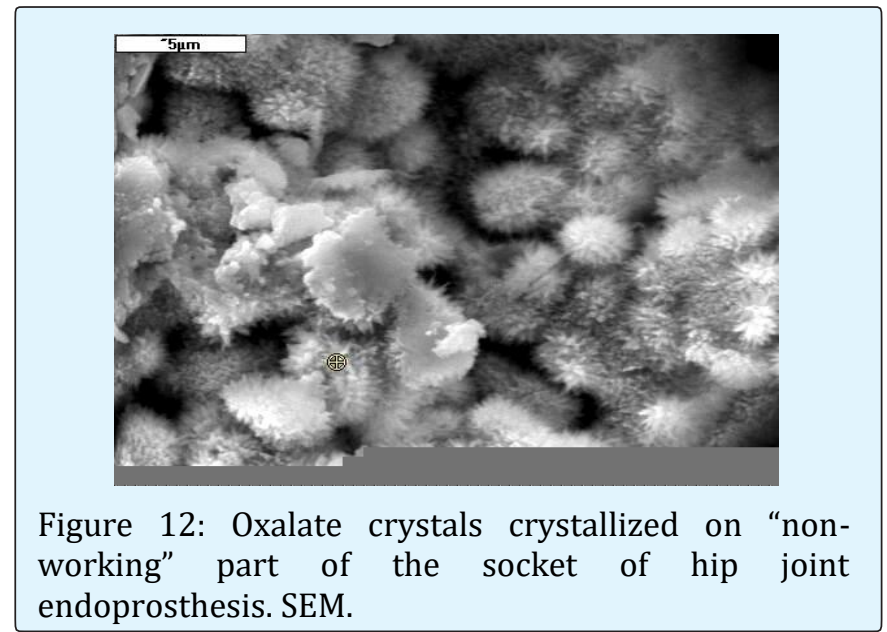

\section{Studies of the Metal Heads of Hip Joint Endoprosthesis}

Tests were carried out on heads of selected endoprostheses (Figure 13) that were removed from Patients during the procedure of endoprosthesis replacement. "Working" fragment, which bore the most load, were cut from the heads of those endoprostheses (Figure 14).

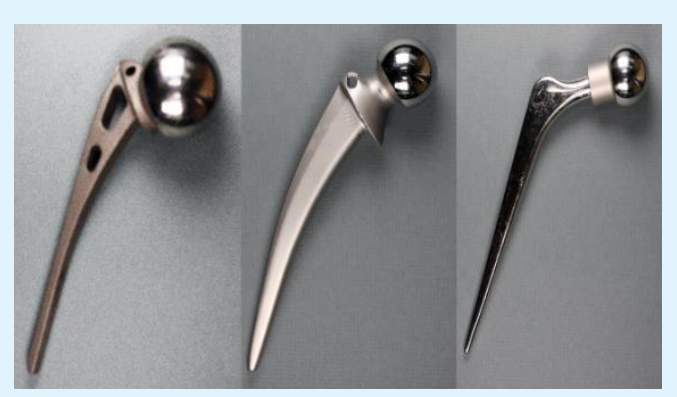

Figure 13: Cleaned metal parts of endoprostheses studied after being removed from patients during endoprosthesis replacement.
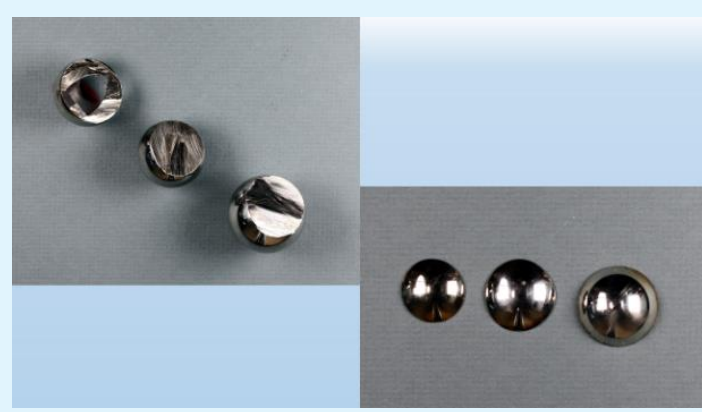

Figure 14: Fragments of cut heads of the endoprostheses. Left - view from the side of endoprosthesis; right - view from the side of the joint.
Studies showed that steels used in production of the endoprostheses are iron-chromium-cobalt steel (heads 1, 2 , left) and iron-chromium-manganese steel with admixture of nickel (head 3, right). Their chemical analyses carried out with EDS method are shown in Figures 15 and 16.

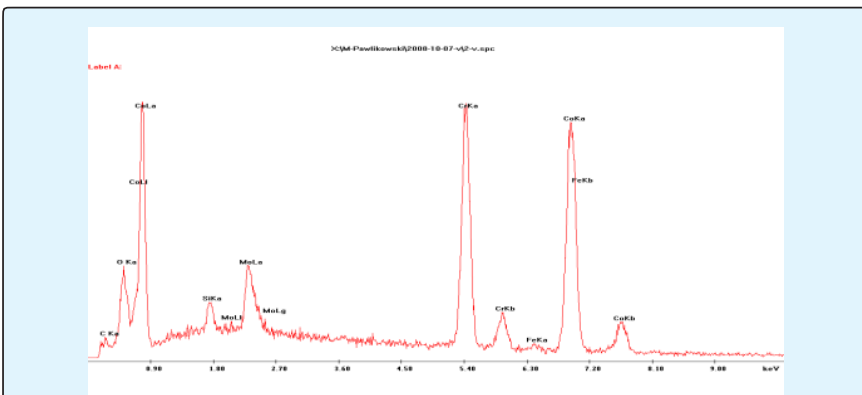

Figure 15: EDS energy spectrum of steel from head 1 (Figure 14).

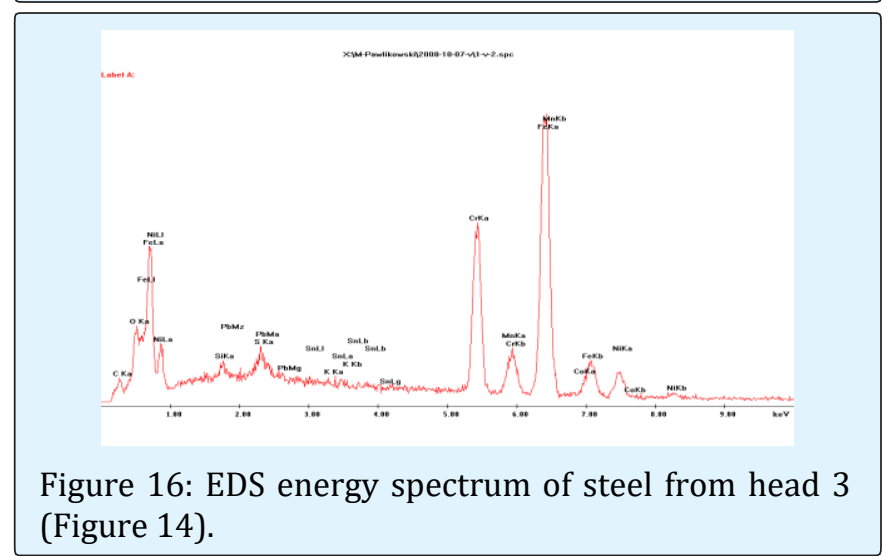

Studies showed that tested steels from the heads of endoprostheses differ not only in chemical composition, but also in structure. Despite their reflective shine, all of them are fine-crystalline and they have different porosity, including different configuration of micropores (Figure 17).

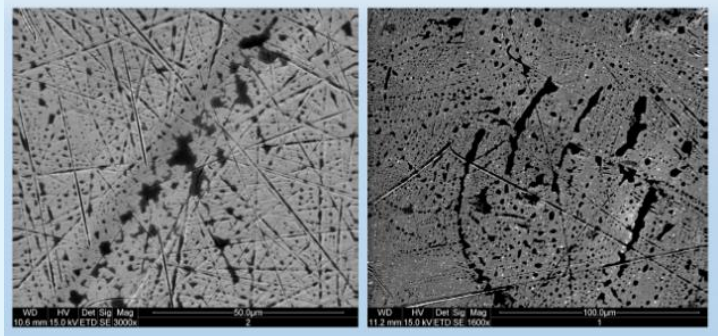

Figure 17: Structure and patterns of microvoids in the heads of the endoprostheses. Left - head of endoprosthesis 1 (Figure 14); right - head of endoprosthesis 3 (Figure 14). SEM. 


\section{International Journal of Transplantation \& Plastic Surgery}

It affects the functioning of the joint of endoprosthesis, including the erosion of the plastic socket surface, because the edges of the voids are exceptionally sharp and can cut the surface of the socket under load.

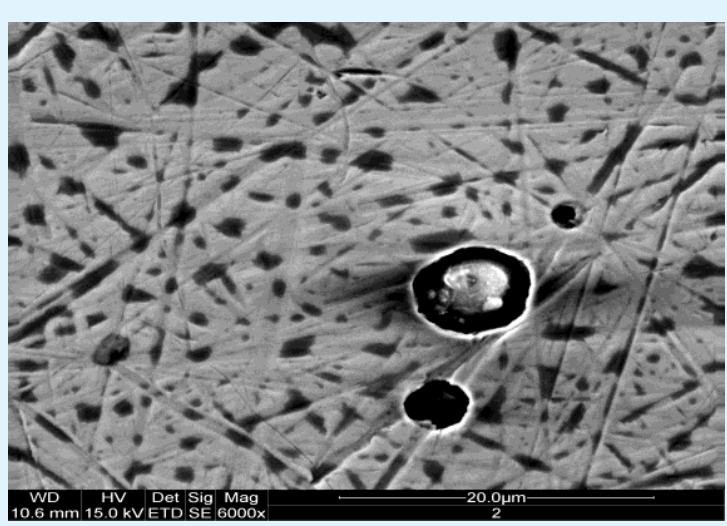

Figure 18: Microslag and a hole remaining after a microslag was torn out in fine-crystalline steel of chromium-nickel head of the endoprosthesis.

During observation of endoprostheses heads surfaces, carried out under scanning microscope, fine silicate and aluminosilicate microslags were found (Figures 17 \& 19). When they get torn out of the steel during the endoprosthesis functioning and find their way into the joint space, they cause significant damage. It can be seen especially on the surface of the soft, plastic socket, but due to their significant hardness, they also damage the surface of the steel head.

Resulting cuts in the surface of the head (Figure 20) act like a sharp knife and damage the socket during movement, causing formation of small fragments. Those in turn may get into the circulatory system, promoting blockages of blood vessels, which may result in swelling of the joint area and gathering of fluid.

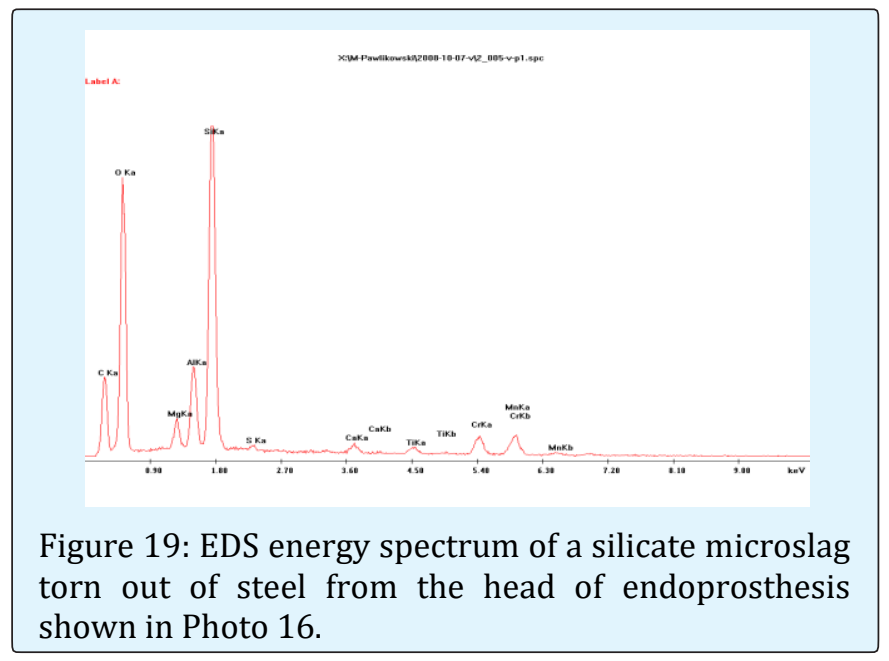

Pawlikowski M. Biomineralogical Phenomena in Hip Joint Endoprostheses. Int J Transplant \& Plastic Surg 2018, 2(2): 000124.

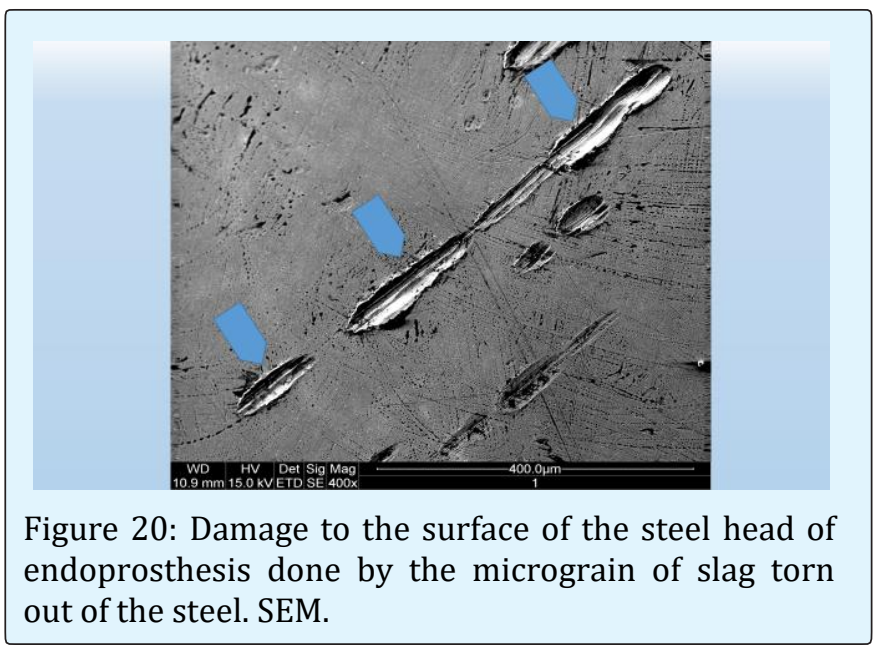

\section{Cements}

In addition to the speed of cement setting and the temperature created in the process, another important matter is its homogeneity. The homogeneity of cement is determined both by the accuracy of mixing the components in the case of two-component cements, as well as the homogeneity of the mixed cement.

In the case of fast mixing of cement components, air gets into the mixture in the form of small bubbles, which may be sealed in the cement mass during its setting (Figure 21). The more bubbles in the cement, the weaker the binding of the endoprosthesis to the bone. The weaker the binding of the endoprosthesis to the bone, the greater the chance of its wavering during functioning.

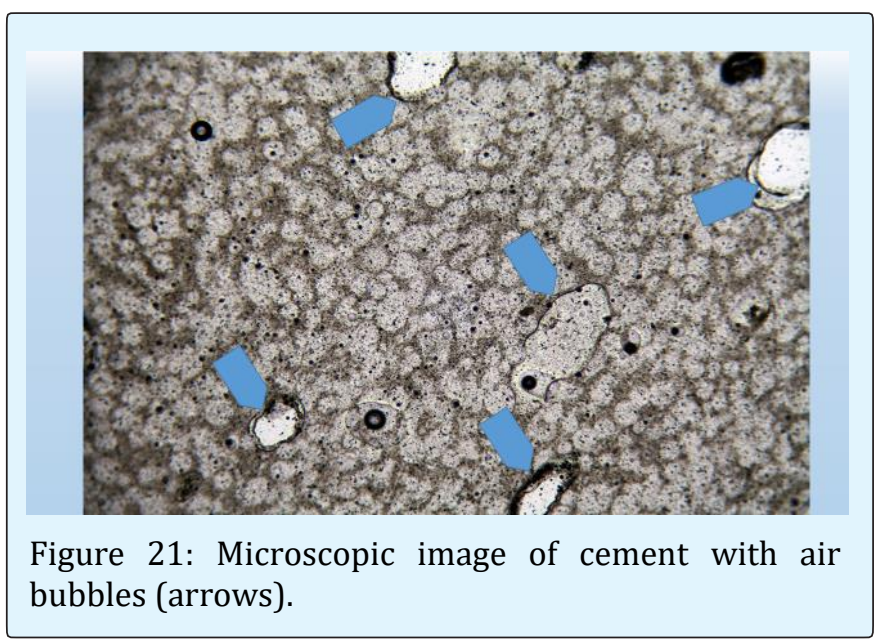

It appears beneficial to mix the components of cements binding the endoprosthesis in a container with pumped-out air. 


\section{International Journal of Transplantation \& Plastic Surgery}

\section{Conclusions}

Presented studies reveal details connected with the stability of endoprostheses, including the matters of the quality of used materials and their modifications as a result of functioning of the endoprostheses. Described phenomena should become the object of interest not only of orthopedic specialists, but especially the manufacturers of endoprostheses. Determining the manufacturer and model of the endoprosthesis decades after its implementation was problematic. Considering the unresolved nature of the data, the author chose not to disclose it.

Translated by K. Wieczorek

\section{References}

1. Bieniek A, Niedźwiedzki T, Pawlikowski M (2011) Badania mineralogiczne zjawisk osteoporozy głów kości udowej, a rentgenowskie badania densytometryczne (Mineralogical investigation of osteoporosis phenomenon - relation to densometric examinantion). Ortopedia, Traumatologia Rehabilitacja. Cong of Polish Osteoarthrology Society and Poslish Fundation of Osteoporosis. Kraków, pp: 150-151.

2. Kita B, Pawlikowski M (1983) Badania mineralogiczno-chemiczne kości udowej człowieka w aspekcie procesu starzenia. (Mineralogical-chemical investigation of tibia in the aspect of ageing). Chirur Narządów Ruchu i Ortop Pol T 43: 87-91.

3. Lipnicka P, Pawlikowski M, Pfitzner R (2003) Znaczenie rozpuszczania syntetycznego hydroksyapatytu w badaniach nad destrukcją złogów miażdżycowych.(An importance of examination of dissolution of hydroxyapatite - relations to mineralization of human artheries). Folia Med Crac v 44(1-2): 187-200.

4. Niedźwiedzki T, Pawlikowski M (1987) Zmiany w mineralnej części kości w pobliżu stawów rzekomych. (Mineralogical changes at the region of ostites). Chirurgia Narz Ruchu i Ortop Pol T 52(2): 100-107.

5. Niedźwiedzki T, Dąbrowski Z, Miszta H, Pawlikowski M (1993) Bone healing after bone marrow stromal cell transplantation to the bone defect. Biomaterials 14(2): 115-121.

6. Niedźwiedzki T, Pawlikowski M, Brudnicki J, Palka E (1995) Zmiany mineralogiczne zachodzące w stawach kręgosłupa w czasie starzenia się (Mineralogical alternetions observed at vertebral column - relations to ageing). Chir Narzów Ruchu i Ortop Pol 60(1): 163167.

7. Pawlikowski M (1987) Mineralizacja organizmu człowieka żyjącego. (Mineralization of human living organism). Prace Mineral pp: 79-121.

8. Pawlikowski M (1991) Gospodarka Ca i P w organizmie człowieka. (Distribution of $\mathrm{Ca}$ and $\mathrm{P}$ in human organism ) In: A Szymański Biomineralogia I biomateriały. PWN Warszawa, pp: 61-66.

9. Pawlikowski M (1993) Kryształy w organizmie człowieka. (Crystals of human organism). Secesja. (Atlas), pp: 132.

10. Pawlikowski M (1994) Mineralizacja tkanek organizmu człowieka jako efekt starzenia. (Mineralization of human tissues as effect of ageing). Prace Spec PTMin Z 5: 196.

11. Pawlikowski M (1995) Sekrety mineralizacji tkanek. (Secrets of tissues mineralization). Wyd IGSMiE PAN Kraków pp: 97.

12. Pawlikowski M (1999) Preliminary results of dissolution of substances mineralizing human arteries. Arch Mineralog T 52: 195-210.

13. Pawlikowski M (2003) Minerals in human blood vessels and their dissolution in vitro. In: Skinner HCW, Berger AW (Eds.), Geology and health. N.Y. Oxford. Oxford Univ Press, pp: 155-158.

14. Pawlikowski M (2004) Mineralogy and chemistry of osteoporosis - mechanism of mineralization (calcification) of human tissues. Prec Goldschmidt Conf Kopenhaga A 531.

15. Pawlikowski M (2011) Osteoporoza jako źródło mineralizacji tkanek. (Osteoporosis as source of elements mineralizing tissues). Materiały Konf. Mechanizmy służące utrzymaniu życia i regulacji fizjologicznych. Kraków, pp: 79-83.

16. Pawlikowski M (2014) Osteoporosis as A Source of Tissue Mineralization Research on Osteoporosis Therapy and Dissolution of Arterial Mineralization. Jour Life Science 8(7): 610-625.

17. Pawlikowski M (2016) Biomineralogy of osteoporosis. Acad J Biotech 4(4): 138-144. 


\section{International Journal of Transplantation \& Plastic Surgery}

18. Pawlikowski M (2017) Centers of Human Tissue Biomineralization (Calcification). Cardiol Cardiovascmed 1 (6): 252-261.

19. Pawlikowski M (in print) The phenomenon of joint cartilage biomineralization. Open Journal of Surgery.

20. Pawlikowski M, Pfitzner R (1995a) Zastosowanie metod mineralogicznych $\mathrm{w}$ badaniach tkanek człowieka. I. Sposoby badania mineralizacji. (Mineralogical methods useful for examination of human tissues). Przegl Lekarski 52(4): 119-123.

21. Pawlikowski M, Pfitzner R (1995b) Zastosowanie metod mineralogicznych $\mathrm{w}$ badaniach tkanek człowieka. II. Mineralizacja struktur serca. (Mineralogical methods useful for examination of human tissues. Mineralization of heart structures). Przegl Lekarski 52(4): 24-27.
22. Pawlikowski M, Pfitzner R (1999) Mineralizacja serca i dużych naczyń. (Mineralzation of hearth and big blood vessels). Wyd IGSMiE PAN Kraków pp: 142.

23. Pawlikowski M, Niedżwiedzki $T$ (2002) Mineralogia kości. (Mineralogy of bones). Wyd PAN Oddział w Krakowie pp: 128.

24. Pawlikowski M, Niedźwiedzki T, Bieniek A, Niedźwiedzki Ł, Olejarz A (2015) Badania mineralogiczne głów i chrząstki stawowej kości udowej u chorych $\mathrm{z}$ jałową martwicą (AVN). (Mineralogical testing of femur heads and joint cartilage of patients with avascular necrosis (AVN), Auxiliary sciences in archaeology, preservation of relicts and environmental engineering. CD -no 20, Ed. M Pawlikowski.

25. Zawistowski S (1965) Technika histologiczna oraz podstawy histopatologii. PZWL, Warszawa. 